\title{
The influence of prostaglandin F-2 $\alpha$ on pregnenolone metabolism by the autotransplanted ovary of the ewe
}

\author{
H. O. Hoppen, * D. M. Williams and J. K. Findlay \\ Reproduction Research Section, Department of Physiology, \\ University of Melbourne, S.S. Cameron Laboratory, Werribee 3030, Australia
}

\begin{abstract}
Summary. Eight ewes each with an autotransplanted ovary received infusions of tritium-labelled pregnenolone $(41 \mu \mathrm{Ci} / \mathrm{hr})$ for $8 \mathrm{hr}$ into the artery supplying the ovary, together with prostaglandin (PG) F-2 2 (30 $\mu \mathrm{g} / \mathrm{hr}$ ) for $3 \mathrm{hr}$ beginning $2 \mathrm{hr}$ after the start of the pregnenolone infusion. All animals exhibited oestrus 2-3 days after the start of the experiment. During the PGF- $2 \alpha$ infusion blood flow through the ovaries was increased by $13 \%$, but subsequently returned to pre-infusion levels. Secretion rates of endogenous progesterone and $20 \alpha$-hydroxypregn-4-en-3-one dropped rapidly $5 \mathrm{hr}$ after the PGF-2 $\alpha$ infusion had started from values of $250 \mu \mathrm{g} / \mathrm{hr}$ and $25 \mu \mathrm{g} / \mathrm{hr}$ to values below $60 \mu \mathrm{g} / \mathrm{hr}$ and $8 \mu \mathrm{g} / \mathrm{hr}$, respectively. At this time the conversion of radioactive pregnenolone to progesterone was reduced by $50 \%$ of its initial value, but the secretion of endogenous pregnenolone and the formation of radioactive metabolites other than progesterone were not diminished. In 4 control animals, which received pregnenolone only, no changes in ovarian blood flow, steroid secretion rates, or in the conversion of labelled pregnenolone were observed. These results suggest a possible involvement of PGF- $2 \alpha$ in the regulation of progesterone biosynthesis by an action on the $3 \beta$-hydroxysteroid oxidoreductase- $\Delta^{5-4}$ isomerase enzyme system.
\end{abstract}

\section{Introduction}

Prostaglandin (PG) F-2 $\alpha$ has been identified as a luteolytic agent (see McCracken et al., 1972) and has been proposed as the natural luteolysin in sheep (Goding, 1974) and other species (Goding et al., 1971/72), but the mechanism of its luteolytic action is still not known. Deane, Hay, Moor, Rowson \& Short (1966) demonstrated that the rapid decline in the secretory activity of the corpus luteum at the end of the oestrous cycle of the ewe was associated with a reduction in the activity of the $3 \beta$-hydroxysteroid oxidoreductase- $\Delta^{5-4}$ isomerase enzyme system responsible for the conversion of pregnenolone to progesterone. The present study was undertaken to investigate the possible involvement of PGF-2 $\alpha$ in the regulation of this enzyme system.

\section{Materials and Methods}

Merino ewes (aged 3-6 years) bearing ovarian autotransplants (Goding, McCracken \& Baird, 1967) were used. The left ovary was transplanted with vascular anastomosis to the carotid artery and the jugular vein which had been exteriorized into a skin loop in the neck. The right ovary was removed. During the 4 weeks before the experiment the sheep were checked daily for oestrous behaviour using

* Present address: Abteilung für Biochemische Endokrinologie der Medizinischen Hochschule Lübeck, 2400 Lübeck, West Germany. 
a ram fitted with Sire-Sine harness. After the presence of a functional $\mathrm{CL}$ was established on the basis of peripheral plasma progesterone levels higher than $1 \mathrm{ng} / \mathrm{ml}$, the animals were placed in metabolism cages at least 2 days before the start of the experiment.

The exteriorized carotid artery was cannulated with an Angiocath teflon catheter (No. 16G, $6.5 \mathrm{~cm}$ long, Desert Pharmaceutical Co., Sandy, Utah), and the jugular vein was cannulated with Silastic tubing (1.7 mm i.d., 3.4 $\mathrm{mm}$ o.d., Dow Corning) as described previously (McCracken, Uno, Goding, Ichikawa \& Baird, 1969). Immediately after inserting the catheter heparinized saline (125,000 units heparin, Commonwealth Serum Labs, Melbourne, in 1 litre of 0.154 M-saline) was infused into the arterial supply of the ovary at a rate of $4.2 \mathrm{ml} / \mathrm{hr}$ for at least $1 \mathrm{hr}$.

A pneumatic cuff (Sphygmomanometer Accosan, England) with $4 \mathrm{~cm}$ baby inflatable cuff was placed around the cranial part of the skin loop and inflated to $160 \mathrm{mmHg}$ so that the arterial supply of the ovary was derived from carotid arterial blood containing the infusate. The $\left[7 \alpha^{-}{ }^{3} \mathrm{H}\right]$ pregnenolone ( $25 \mathrm{Ci} / \mathrm{mmol}$, NEN, Boston), dissolved in heparinized saline containing $20 \%(\mathrm{v} / \mathrm{v})$ of the animal's own peripheral plasma as solubilizer, was infused at a rate of $41 \mu \mathrm{Ci} / \mathrm{hr}(0.5 \mu \mathrm{g} / \mathrm{hr}, 4.2 \mathrm{ml} / \mathrm{hr})$ for $8 \mathrm{hr}$. Two hours after the beginning of the pregnenolone infusion, PGF-2 $\alpha$ (Fuji Chemical Industries Ltd, Tokyo) was infused with the radioactive steroid for a further $3 \mathrm{hr}$ at a rate of $30 \mu \mathrm{g} / \mathrm{hr}$ (see Text-fig. 1). This dose has previously been shown to be luteolytic in sheep (Chamley et al., 1972). Eight ewes received this infusion and 4 ewes, which received $\left[7 \alpha_{-}{ }^{3} \mathrm{H}\right]$ pregnenolone alone for $8 \mathrm{hr}$, served as controls.

Blood flow was measured as described by McCracken et al. (1969). Samples (10 ml) of ovarian venous and peripheral blood were collected in heparinized tubes every hour, the plasma and red cells were separated by centrifugation and both fractions stored at $-20^{\circ} \mathrm{C}$ for measurement of radioactivity and hormone analysis. Haematocrit levels were determined in each sample and steroid secretion rates were calculated from their respective concentrations in plasma and red cells, blood flow rate and haematocrit. Progesterone was measured by a radioimmunoassay adaptation of the method of Cain et al. (1972). The antiserum was raised in rabbits against $6 \beta$-hydroxyprogesteronehemisuccinate-bovine serum albumin and the radioimmunoassay has the same accuracy and precision as described by Cain et al. (1972). At 50\% displacement the cross-reactivity with other steroids was $100 \%$ with progesterone; $30 \%$ with pregnenolone; $114 \%$ with $5 \alpha$-pregnan-3,20-dione; $10.9 \%$ with $5 \beta$-pregnan-3,20-dione; $6.6 \%$ with $5 \alpha$-pregnan- $3 \beta$-ol-20-one; $4.7 \%$ with $20 \beta$-hydroxypregn-4-en-3-one; $4.6 \%$ with $17 \alpha$-hydroxyprogesterone; $3.2 \%$ with $11 \alpha$-hydroxyprogesterone; $2.0 \%$ with $11 \beta$-hydroxyprogesterone; $1.7 \%$ with $16 \alpha$-hydroxyprogesterone; and $<0.2 \%$ with $20 \alpha$-hydroxypregn-4-en-3-one, androstendione, testosterone and oestradiol-17 $\beta$. Because of the small sample volume (1-2 $\mu 1)$ of ovarian venous plasma there was no interference in the assay by the radioactivity incorporated in progesterone. For the isolation and identification of radioactive metabolites large samples $(100 \mathrm{ml})$ of ovarian venous blood were collected from all ewes before and $5 \mathrm{hr}$ after starting the PGF- $2 \alpha$ infusion, i.e. at 2 and $7 \mathrm{hr}$ after starting the infusion of $\left[7 \alpha^{3}{ }^{3} \mathrm{H}\right]$ pregnenolone. Plasma and red cells were separated by centrifugation and extracted 3 times with equal volumes of ethyl acetate after washing the red cells twice with heparinized saline and then rupturing the red cell membranes by repeated freezing and thawing. The pooled ethyl acetate layers were washed 3 times with $5 \mathrm{ml}$ water, dried with sodium sulphate and the solvent was evaporated in vacuo. The dry residues were redissolved and fractionated on Sephadex LH-20 columns (gel bed $1 \times 20 \mathrm{~cm}$ : Pharmacia, Sweden) with $52 \mathrm{ml}$ solvent system I ( $n$-heptane: benzene:methanol, $85: 10: 5$ by vol.) and then with $40 \mathrm{ml}$ solvent system II ( $n$-heptane: benzene: methanol, $40: 40: 10$ by vol.). The eluate was collected in $4 \mathrm{ml}$ portions. Further purification was achieved by thin-layer chromatography (TLC 1: chloroform: ethyl acetate, 9:1 v/v; TLC 2: chloroform:methanol, 95:5, v/v) using a continuous flow chamber (Shandon Ltd, London). Procedural losses were corrected for by the method of Knuppen et al. (1969). For final identification steroids were converted to methoximetrimethylsilyl derivatives (Engel, Neville, Orr \& Raggat, 1970) for GLC-MS, using an LKB 9000 instrument (LKB produkter, Bromma, Sweden) under the operation conditions described previously (Hoppen \& Siekmann, 1974).

Pregnenolone and 20a-hydroxypregn-4-en-3-one were estimated from aliquots of the $100 \mathrm{ml}$ samples by GLC-MS using a mass fragmentography technique (L. Siekmann \& H. O. Hoppen, 
unpublished results). As radioactive pregnenolone and 20a-hydroxypregn-4-en-3-one differed from the endogenous steroid by 2 mass units, it was possible to measure endogenous steroid only.

\section{Results}

\section{Blood flow}

There was a large variation between blood flow through the ovary of the individual animals. During PGF-2 $\alpha$ infusion the average blood flow (about $900 \mathrm{ml} / \mathrm{hr}$ ) increased to values $13 \%$ above the pre-infusion figures ( $t$ test for paired samples, $0.025>P>0.0125$ ).

\section{Steroid secretion by the ovary}

Progesterone secretion rate dropped rapidly to values below $60 \mu \mathrm{g} / \mathrm{hr}$ by $5 \mathrm{hr}$ after beginning the PGF-2 $\alpha$ infusion, but remained at the pre-infusion level $(250 \mu \mathrm{g} / \mathrm{hr})$ in the 4 control sheep which

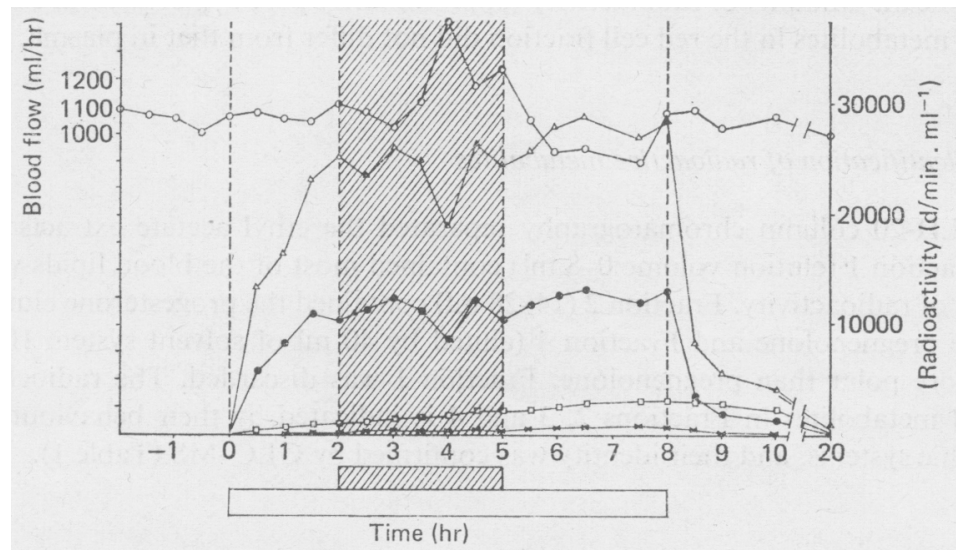

Text-fig. 1. The radioactivity in peripheral and ovarian venous blood and total ovarian blood flow $(O)$ after infusion of $\left[7 \alpha_{-}{ }^{3} \mathrm{H}\right]$ pregnenolone (open bar) and PGF-2 $\alpha$ (cross-hatched bar) into the arterial supply of the autotransplanted ovary of one ewe. Radioactivity in: $\triangle$, ovarian venous plasma; $\bullet$, ovarian venous red cells; $\square$, peripheral plasma; and $\rightarrow$, peripheral red cells.

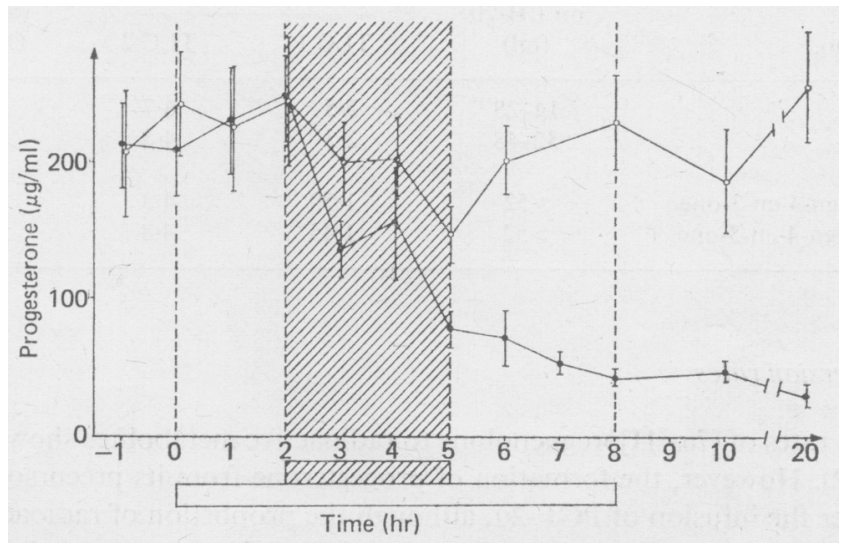

Text-fig. 2. Ovarian progesterone secretion rates (mean \pm S.E.M.) after infusion of $\left[7 \alpha_{-}{ }^{3} \mathrm{H}\right]$ pregnenolone (open bar) and PGF-2 $\alpha$ (cross-hatched bar) into the arterial supply of the autotransplanted ovary in 8 ewes $(\bullet)$, and in 4 control ewes which received $\left[7 \alpha-{ }^{3} \mathrm{H}\right]$ pregnenolone alone $(O)$. 
received pregnenolone alone (Text-fig. 2). The progesterone concentration in peripheral plasma fell from $1.5-5.5 \mathrm{ng} / \mathrm{ml}$ to $<1 \mathrm{ng} / \mathrm{ml}$ after PGF-2 $\alpha$, then gradually increased 4-5 days after oestrus, indicative of ovulation and subsequent formation of a new CL. All animals treated with PGF-2 $\alpha$ came into oestrus 48-72 hr after the start of the PGF- $2 \alpha$ infusion.

The secretion rate (mean \pm S.E.M.) of endogenous $20 \alpha$-hydroxypregn-4-en-3-one fell within $5 \mathrm{hr}$ of PGF-2 $\alpha$ infusion from $24 \cdot 7 \pm 5$ to $8 \cdot 8 \pm 1 \mu \mathrm{g} / \mathrm{hr}$, whilst the secretion of endogenous pregnenolone was not affected $(1.8 \pm 0.4 \mu \mathrm{g} / \mathrm{hr}$ before PGF- $2 \alpha$ compared to $2.4 \pm 0.5 \mu \mathrm{g} / \mathrm{hr} 5 \mathrm{hr}$ later).

\section{Distribution of radioactivity}

Preliminary experiments indicated that the radioactivity in ovarian venous blood reached a plateau 1-2 hr after starting the infusion of radioactive pregnenolone into the arterial supply of the ovary (Text-fig. 1). Radioactivity in peripheral venous blood never exceeded $10 \%$ of the value found in ovarian venous blood even after an 8 - $\mathrm{hr}$ infusion. Therefore the contribution of metabolites of peripheral origin to those measured in ovarian venous blood was negligible. The red blood cells contained significant amounts of radioactivity (approximately $20-30 \%$ of plasma content), but the distribution of metabolites in the red cell fraction did not differ from that in plasma.

\section{Isolation and identification of radioactive metabolites}

Sephadex LH-20 column chromatography separated the ethyl acetate extracts of blood into 4 fractions. Fraction 1 (elution volume $0-8 \mathrm{ml}$ ) contained most of the blood lipids which included small amounts of radioactivity. Fraction $2(14-28 \mathrm{ml})$ contained the progesterone eluted, Fraction 3 $(32-48 \mathrm{ml})$ the pregnenolone and Fraction 4 (eluted by $40 \mathrm{ml}$ of solvent system II) included the metabolites more polar than pregnenolone. Fraction 1 was discarded. The radiochemical purity of the labelled metabolites in Fractions 2, 3 and 4 is indicated by their behaviour in 3 different chromatographic systems, and their identity was confirmed by GLC-MS (Table 1).

Table 1. Identification of metabolites of $\left[7 \alpha-{ }^{3} \mathrm{H}\right]$ pregnenolone after infusion in ewes in various fractions following chromatography of blood extracts on Sephadex LH-20; GLC retention values are given relative to that of oestrone3-methyl ether

\begin{tabular}{|c|c|c|c|c|c|c|}
\hline & \multirow[b]{2}{*}{ Fraction no. } & \multirow{2}{*}{$\begin{array}{l}\text { Elution vol. } \\
\text { on LH-20 } \\
\text { (ml) }\end{array}$} & \multicolumn{2}{|c|}{ Mobilities $(\mathrm{cm} / \mathrm{hr})$} & \multirow{2}{*}{$\begin{array}{c}\text { GLC retention } \\
\text { value on } \\
\text { OV-101 }\end{array}$} & \multirow{2}{*}{$\begin{array}{c}\text { Mol. w } \\
(m / e)\end{array}$} \\
\hline & & & TLC 1 & TLC 2 & & \\
\hline 2 & (progesterone) & $14-28$ & $3 \cdot 5$ & $6 \cdot 7$ & $2 \cdot 90$ & 372 \\
\hline 3 & (pregnenolone) & $32-48$ & $2 \cdot 3$ & $4 \cdot 8$ & $2 \cdot 50$ & 417 \\
\hline \multirow[t]{3}{*}{4} & (polar) & & & & & \\
\hline & $20 \alpha$-hydroxypregn-4-en-3-one & $>52$ & $1 \cdot 50$ & $4 \cdot 3$ & $3 \cdot 05$ & 417 \\
\hline & $20 \beta$-hydroxypregn-4-en-3-one & $>52$ & 1.45 & $4 \cdot 8$ & $3 \cdot 28$ & 417 \\
\hline
\end{tabular}

\section{Pregnenolone conversion rates}

The conversion rates of $\left[7 \alpha_{-}{ }^{3} \mathrm{H}\right]$ pregnenolone to radioactive metabolites showed great individual variations (Table 2). However, the formation of progesterone from its precursor clearly decreased in each animal after the infusion of PGF-2 $\alpha$, although the proportion of radioactivity found in the polar and non-polar fractions did not appear to be altered. In the control animals there was no alteration of pregnenolone metabolism and no change in the specific radioactivity of progesterone even though the differences between individuals were large (Table 2). 
Table 2. The percentage conversion of $\left[7 \alpha-{ }^{3} \mathrm{H}\right]$ pregnenolone to radioactive metabolites $(\Delta 4 \mathrm{P}=$ progesterone, $\Delta 5 \mathrm{P}=$ pregnenolone, $\mathrm{n} . \mathrm{d} .=$ not determined) by the autotransplanted sheep ovary before and 5 hr after treatment with PGF-2 $\alpha$

\begin{tabular}{|c|c|c|c|c|c|c|c|c|c|c|}
\hline \multirow{2}{*}{\multicolumn{2}{|c|}{$\begin{array}{c}\text { Experiment } \\
\text { no. }\end{array}$}} & \multicolumn{4}{|c|}{ Metabolites before PGF-2 $\alpha$} & \multicolumn{4}{|c|}{ Metabolites after PGF- $2 \alpha$} & \multirow{2}{*}{$\begin{array}{l}\text { Amount of } \triangle 4 \mathrm{P} \text { formed } \\
5 \mathrm{hr} \text { after PGF-2 } \alpha \\
\text { (as } \% \text { of initial value) }\end{array}$} \\
\hline & & Non-polar & $\Delta 4 \mathrm{P}$ & $\Delta 5 \mathrm{P}$ & Polar & Non-polar & $\Delta 4 \mathrm{P}$ & $\Delta 5 \mathrm{P}$ & Polar & \\
\hline \multirow[t]{2}{*}{1} & Plasma & n.d. & 46.9 & $53 \cdot 1$ & n.d. & n.d. & $24 \cdot 3$ & $75 \cdot 7$ & n.d. & 52 \\
\hline & Red cells & n.d. & $46 \cdot 4$ & 53.6 & n.d. & n.d. & 20 & 80 & n.d. & 43 \\
\hline \multirow[t]{2}{*}{2} & Plasma & $13 \cdot 7$ & 15.9 & $36 \cdot 1$ & 34.5 & $15 \cdot 6$ & 8.9 & $53 \cdot 9$ & $21 \cdot 5$ & 56 \\
\hline & Red cells & $14 \cdot 3$ & $14 \cdot 9$ & $33 \cdot 2$ & $37 \cdot 6$ & $21 \cdot 4$ & $7 \cdot 3$ & $51 \cdot 2$ & $20 \cdot 2$ & 49 \\
\hline \multirow[t]{2}{*}{3} & Plasma & 10 & 29 & $51 \cdot 5$ & 9 & $5 \cdot 9$ & 15 & 69.9 & $9 \cdot 1$ & 52 \\
\hline & Red cells & 9 & $31 \cdot 5$ & $49 \cdot 5$ & 10 & 3 & 13.9 & $72 \cdot 9$ & $10 \cdot 1$ & 44 \\
\hline 4 & Red cells & $9 \cdot 2$ & $12 \cdot 7$ & $38 \cdot 3$ & 40 & $8 \cdot 6$ & $4 \cdot 4$ & $66 \cdot 7$ & $20 \cdot 3$ & 35 \\
\hline \multirow[t]{2}{*}{5} & Plasma & $10 \cdot 7$ & $19 \cdot 2$ & $61 \cdot 8$ & $8 \cdot 3$ & $13 \cdot 4$ & $11 \cdot 3$ & $60 \cdot 8$ & $14 \cdot 4$ & 59 \\
\hline & Red cells & 3 & $18 \cdot 4$ & $55 \cdot 6$ & $22 \cdot 8$ & $7 \cdot 5$ & $7 \cdot 6$ & $65 \cdot 4$ & $19 \cdot 3$ & 41 \\
\hline 6 & Plasma & 6.9 & 30.4 & $52 \cdot 2$ & $10 \cdot 6$ & $9 \cdot 5$ & $15 \cdot 7$ & 63.4 & $11 \cdot 5$ & 52 \\
\hline 7 & Plasma & $7 \cdot 8$ & $21 \cdot 8$ & $58 \cdot 2$ & $12 \cdot 1$ & $9 \cdot 4$ & 9 & $60 \cdot 5$ & $21 \cdot 1$ & 41 \\
\hline$* 9$ & Plasma & 5.9 & 20.4 & $50 \cdot 5$ & $21 \cdot 3$ & 18 & $27 \cdot 8$ & $40 \cdot 6$ & $13 \cdot 7$ & 136 \\
\hline$* 10$ & Plasma & $12 \cdot 8$ & $22 \cdot 8$ & $23 \cdot 6$ & $40 \cdot 9$ & $21 \cdot 9$ & 22.5 & $27 \cdot 7$ & $27 \cdot 9$ & 98 \\
\hline$* 11$ & Plasma & $13 \cdot 7$ & 18 & $44 \cdot 2$ & $24 \cdot 2$ & $18 \cdot 7$ & $20 \cdot 4$ & $42 \cdot 1$ & $19 \cdot 2$ & 112 \\
\hline$* 12$ & Plasma & 10 & 30 & $49 \cdot 1$ & 10.8 & $8 \cdot 4$ & $27 \cdot 3$ & 48 & $15 \cdot 7$ & 91 \\
\hline
\end{tabular}

* Control ewes received pregnenolone only and samples were taken at the same times as for the experimental animals.

\section{Discussion}

Several mechanisms have been proposed to explain the luteolytic action of PGF-2 $\alpha$ in the ewe. These include a vasoconstrictive reduction of total ovarian blood flow causing necrosis of luteal cells (Pharriss, Tillson \& Erickson, 1972), selective reduction in blood flow to the CL (Thorburn \& Hales, 1972; Bruce \& Moor, 1975), antagonism towards luteotrophins at the luteal cell membrane (Behrman, Grinwich \& Hichens, 1975), and an inhibitory action on enzymes involved in the biosynthesis of progesterone (for a summary see Wilks, Forbes \& Norland, 1973).

Data published for the sheep (Baird, 1974; Einer-Jensen \& McCracken, 1975) and those presented in this paper clearly demonstrate that changes in total ovarian blood flow cannot account for the dramatic fall in progesterone secretion which is seen after treatment with PGF- $2 \alpha$. In our experiments a slight increase in total ovarian blood flow similar to that found by Einer-Jensen \& McCracken (1975) was observed during PGF-2 $\alpha$ infusion, whereas Baird (1974) reported a slight depression of flow rates, both changes being reversible. A possible explanation for this discrepancy could be the different PGF-2 $\alpha$ doses: Baird (1974) infused with $40 \mu \mathrm{g} / \mathrm{hr}$ for $4 \mathrm{hr}$ compared with our $30 \mu \mathrm{g} / \mathrm{hr}$ for $3 \mathrm{hr}$.

Experiments designed to demonstrate a selective reduction in blood flow to the CL have not produced consistent results. Microsphere studies have demonstrated a reduction in luteal blood flow in sheep undergoing normal luteal regression (Niswender, Diekmann, Nett \& Akbar, 1973; Bruce \& Moor, 1975), or treated with PGF-2 $\alpha$ (Thorburn \& Hales, 1972). This effect has not been verified in similar studies using ${ }^{85} \mathrm{Kr}$ for measuring capillary flow (Einer-Jensen \& McCracken, 1975) in sheep with autotransplanted or in-situ ovaries. However, the failure of PGF-2 $\alpha$ to cause luteolysis after direct injection into the CL (Chamley \& O'Shea, 1976) suggests the involvement of a vascular component in the mechanism of action of PGF- $2 \alpha$.

Behrman et al. (1975) have evidence from experiments in vivo with rats which suggests that PGF-2 $\alpha$ might exert its luteolytic action by reducing the number of $\mathrm{LH}$ receptors on the luteal cell membrane, this effect being blocked by prolactin. Studies with the ovine autotransplant preparation showed that high doses of either LH or prolactin failed to block the luteolytic action of PGF- $2 \alpha$ when both the pituitary hormone and PGF- $2 \alpha$ were infused concurrently (Cerini, Chamley, Findlay \& Goding, 1973; Chamley, Cerini \& Goding, 1973). The action of PGF-2 $\alpha$ in the presence of LH and prolactin together has yet to be studied. 
The results presented in this paper suggest that PGF- $2 \alpha$ might have a direct inhibitory action on the enzymes in the $\mathrm{CL}$ which convert pregnenolone to progesterone. The fall in progesterone secretion was accompanied by a significant decrease in the secretion of $20 \alpha$-hydroxypregn-4-en-3-one whereas no overall change in endogenous pregnenolone secretion was evident. No changes in progesterone secretion rates were detected in control animals. Mass fragmentography is a highly specific method of hormone assay and this may explain why the pregnenolone values are lower than values published by others (Short, MacDonald \& Rowson, 1963; Baird, McCracken \& Goding, 1973). The 20 $\alpha$-hydroxypregn-4-en-3-one secretion rates are in agreement with other values for the autotransplanted ovary (McCracken, Baird \& Goding, 1971) and those from studies of ovaries in situ (Short et al., 1963; Lindner, Sass \& Morris, 1964) in the ewe.

Demers, Behrman \& Greep (1973) and O'Grady et al. (1972) demonstrated that PGF-2 $\alpha$ induced a reduction in progestin synthesis by cultured rabbit or rat luteal tissue. Wilks et al. (1973) confirmed these findings but were unable to verify the stimulatory effect of PGF- $2 \alpha$ on progesterone biosynthesis by rat or rabbit luteal tissue in vitro, as has been reported for other species (see Wilks et al., 1973). Whilst the data in this paper support an action of PGF- $2 \alpha$ on the $3 \beta$-hydroxysteroid oxidoreductase$\Delta^{5-4}$ isomerase enzyme system which converts pregnenolone to progesterone, it will be necessary to demonstrate whether this effect occurs earlier than $5 \mathrm{hr}$ after PGF-2 $\alpha$ treatment and precedes any vascular effects.

This work was supported by the Deutsche Forschungsgemeinschaft, the Australian Research Grants Committee and the Australian Wool Research Trust Fund. The technical assistance of Paul Weston and the provision of facilities on the State Research Farm, Werribee, by the Director of Agriculture, Victoria, are gratefully acknowledged.

\section{References}

BaIRD, D.T. (1974) Prostaglandin $F_{2 \alpha}$ and ovarian blood flow in sheep. $J$. Endocr. 62, 413-414.

Baird, D.T., MCCracken, J.A. \& Goding, J.R. (1973) Studies in steroid synthesis and secretion with the autotransplanted sheep ovary and adrenal. In The Endocrinology of Pregnancy and Parturition. Experimental Studies in Sheep, pp. 5-21. Ed. C. G. Pierrepoint. Alpha Omega Alpha Publishing Co., Cardiff.

Behrman, H.R., Grinwich, D.L. \& Hichens, M. (1975) Control of $\mathrm{LH}$ action by prostaglandin $\mathrm{F}_{2 \alpha}$. Int . Conf. Prostaglandins, Florence, pp. 167-168, Abstr

BRUCE, N.W. \& MOOR, R.M. (1975) Ovarian follicular blood flow in the sheep.J. Reprod. Fert. 43, 392-393, Abstr.

Cain, M.D., Cerini, J.C., Cerini, M.E.D., Chamley, W.A., Cumming, I.A. \& Goding, J.R. (1972) Competitive protein binding analysis of ovine and bovine plasma progesterone. J. Reprod. Fert. 28, $148-150$.

Cerini, M.E.D., Chamley, W.A., Findlay, J.K. \& GodING, J.R. (1973) Luteolysis in sheep with ovarian autotransplants following concurrent infusions of luteinizing hormone and $\mathrm{PGF}_{2 \alpha}$ into the ovarian artery. Prostaglandins 3, 399-404.

Chamley, W.A., Cerini, J.C. \& Goding, J.R. (1973) Luteal function in sheep with ovarian autotransplants given concurrent infusions of prolactin and $\mathbf{P G F}_{2 \alpha}$ into the ovarian artery. Prostaglandins 4, 711-716.

Chamley, W.A., Buckmaster, J.M., Cain, M.D., Cerini, J., Cerini, M.E., Cumming, I.A. \& Goding, J.R. (1972) The effect of prostaglandin $F_{2 \alpha}$ on progesterone, oestradiol and luteinizing hormone secretion in sheep with ovarian transplants. $J$. Endocr. 55, 253-263.

Chamley, W.A. \& O'Shea, J.D. (1976) Luteal function in sheep injected with prostaglandin $F_{2 \alpha}$ directly into the corpus luteum. Prostaglandins 11, 133-142.

Deane, H.W., Hay, M.F., Moor, R.M., Rowson, L.E.A. \& SHORT, R.V. (1966) The corpus luteum of the sheep: relationships between morphology and function during the oestrous cycle. Acta endocr., Copenh. 51, 245-263.

Demers, L.M., Behrman, H.R. \& Greep, R. (1973) Effects of prostaglandins and gonadotropins on luteal prostaglandin and steroid biosynthesis. Adv. Biosci. 9, 701-707.

Einer-Jensen, N. \& MCCRACKen, J.A. (1975) ${ }^{85}$ Krypton measurement of capillary blood flow in the ovine corpus luteum during $\mathrm{PGF}_{2 \alpha}$ induced luteolysis. Int. Conf. Prostaglandins, Florence, p. 109, Abstr

Engel, L.L., Neville, A.M., OrR, J.C. \& RagGat, P.R. (1970) Quantitative gas chromatography of steroid methoximetrimethylsilyl ethers. Steroids 16, 377-386.

Goding, J.R. (1974) The demonstration that PGF PG $_{2 \alpha}$ is the uterine luteolysin in the ewe. J. Reprod. Fert. 38, 261-271.

Goding, J.R., Cumming, I.A., Chamley, W.A., Brown, J.M., Cain, M.D., Cerini, J.C., Cerini, M.E.D., Findlay, J.K., O'Shea, J.D. \& Pemberton, D.H. (1971/72) Prostaglandin $F_{2 x}$, "the" luteolysin in the mammal? Hormones and Antagonists Gynec. Invest. 2, 73--97.

Goding, J.R., McCracken, J.A. \& Baird, D.T. (1967) The study of ovarian function in the ewe by means 
of a vascular autotransplantation technique. $J$. Endocr. 39, 37-52.

Hoppen, H.O. \& SiekmanN, L. (1974) Gas chromatography-mass spectrometry of catechol estrogens. Steroids 23, 17-34.

Knuppen, R., Lubrich, W., Haupt. O., Ammerlahn, U. \& BREUeR, H, (1969) Beeinflussung der enzymatischen Methylierung von Catecholaminen durch Östrogene und vice versa. Hoppe-Seyler's Z, physiol. Chem. 350, 1067-1075.

Lindner, H.R., SASS, M.B. \& Morris, B. (1964) Steroids in the ovarian lymph and blood of conscious ewes. J. Endocr. 30, 361-376.

McCracken, J.A., Uno, A., Goding, J.R., IchiKawa, Y. \& BAIRD, D.T. (1969) The in vivo effect of sheep pituitary gonadotrophins on the secretion of steroids by the autotransplanted ovary of the ewe. J. Endocr. 45, 425-440.

MCCracken, J.A., BAiRd, D.T. \& Goding, J.R. (1971) Factors affecting the secretion of steroids from the autotransplanted ovary in the sheep. Recent Prog. Horm. Res. 27, 537-582.

McCracken, J.A., Carlson, J.C., Glew, M.E., Goding, J.R., Baird, D.T., Green, K. \& SamuelssoN, B. (1972) Prostaglandin $F_{2 \alpha}$ identified as a luteolytic hormone in sheep. Nature, New Biol. 238, 129-134.

Niswender, G.D., Diekmann, M.A., Nett, T.M. \& Akbar, A.M. (1973) Relative blood flow to the ovaries of cycling and pregnant ewes. Biol. Reprod. 9, 87, Abstr.

O'Grady, J.P., Kohorn, E.I., Glass, R.H., Caldwell, B.V., Brock, W.A. \& Speroff, L. (1972) Inhibition of progesterone synthesis in vitro by prostaglandin $\mathrm{F}_{2 \alpha} . J$. Reprod. Fert. 30, 153-156.

Pharriss, B.B., Tillson, S.A. \& Erickson, R.R. (1972) Prostaglandins in luteal function. Recent Prog. Horm. Res. 28, 51-73.

Short, R.V., McDonald, M.F. \& Rowson, L.E.A. (1963) Steroids in the ovarian venous blood of ewes before and after gonadotrophic stimulation. $J$. Endocr. 26, 155-169.

Thorburn, G.D. \& Hales, J.R.S. (1972) Selective reduction in blood flow to the ovine corpus luteum after infusion of prostaglandin $F_{2 \alpha}$ into a uterine vein. Proc. Aust. Physiol. Pharmac. Soc. 3, 145, Abstr.

Wilks, J.W., Forbes, K.W. \& Norland, J.F. (1973) Prostaglandins and in vitro ovarian progestin biosynthesis. Prostaglandins 3, 427-437.

Received 24 November 1975 